\title{
Creditor rights, culture and dividend payout policy
}

\author{
Julie Byrne ${ }^{\mathrm{a}}$, Thomas O'Connor ${ }^{\mathrm{b}, *}$ \\ a UCD Smurfit Graduate Business School, University College Dublin, Carysfort Avenue, Blackrock, Co. Dublin, Ireland \\ ${ }^{\mathrm{b}}$ Department of Economics, Finance and Accounting, Maynooth University, National University of Ireland Maynooth, Maynooth, Co. \\ Kildare, Ireland
}

\section{A R T I C L E I N F O}

\section{Article history:}

Received 16 July 2016

Received in revised form 7 December 2016

Accepted 16 December 2016

Available online 23 December 2016

\section{JEL classification:}

G30

G35

\section{Keywords:}

National culture

Creditor rights

Dividend policy

\begin{abstract}
A B S T R A C T
We study how creditor rights and culture interact with one another to influence corporate dividend payout policy. Where creditor rights are strong, creditors accept the status quo, which are large dividends in individualist and small dividends in collectivist traditions, respectively. Culture influences dividend payout where creditor rights are weak. In collectivist countries where group cohesion among corporate stakeholders results in perceived lower agency costs of debt and equity, creditors place few if any restrictions on dividend payout given weak creditor rights. In contrast, in individualist traditions, creditors continue to restrict dividend payouts under weak creditor rights. Our findings emphasize the importance of accounting for the interactions between creditor rights and culture in determining dividend policy.
\end{abstract}

(c) 2016 Elsevier B.V. All rights reserved.

\section{Introduction}

Dividend payout policy research has evolved to consider the possibility that factors' other than firm-level characteristics, such as the law and national culture may influence dividend policy. Aggarwal and Goodell (2014, p. 107) suggest that "traditional finance journals are clearly quite deficient in their attention to culture and finance". In reviewing the role that culture, social trust, and institutions play in determining transactions costs, they assert that "all finance research should include and reflect factors related to these softer measures in addition to traditional economic and financial factors" (Aggarwal and Goodell, 2014, p. 106). In this paper we examine how creditor rights and culture interact with one another to influence corporate dividend payout policy.

We draw together two strands of the dividend literature and study their interaction. The first strand, the dividend-creditor rights literature, demonstrates that creditor rights, a formal institution, exert a sizable influence over corporate dividend payouts. Brockman and Unlu (2009) test the La Porta et al. (2000) equity-only agency models of dividends inclusive of the agency costs of debt and show that it is creditors and not shareholders that exert the greatest influence over corporate dividend policy. Where creditor rights are weak, managers cater to the demands of creditors for lower dividends (the substitution hypothesis). Where creditor and shareholders rights are strong, creditors permit large dividend payouts (see Byrne and O'Connor, 2012; Shao et al., 2013). The second strand, the dividend-culture literature, explores the link between culture, an informal institution, and corporate dividend payout in a purely agency cost of equity setting. Fidrmuc and Jacob (2010) show that dividend payouts are necessary large in individualist cultures because individuals pursue the individual

\footnotetext{
* Corresponding author.

E-mail address: thomas.g.oconnor@nuim.ie (T. O’Connor).
} 
rather than the collective goal, but are much lower where a sense of collectivism prevails. In individualist traditions large dividends compensate for the severity of the agency conflict which arises between insiders and outsiders. There is no need for large dividend payouts in collectivist traditions because of the close links and the sense of group cohesion which is fostered between insiders and outsiders.

The dividend-creditor rights and dividend-culture literatures are distinct from one another, a distinction highlighted by the proponents of the dividend-culture viewpoint. They emphasize that agency conflicts are determined not only by an objective assessment of the severity of agency conflicts which is provided by legal rules, but also by a subjective assessment among individuals of the perceived extent of agency conflicts, which is captured by culture. Furthermore, measures of creditor rights (culture) do not fully account for differences in culture (creditor rights) across countries, resulting in instances in which the objective assessment of the extent of agency conflicts provided by legal variables may be very different to the culturally determined perception of these same agency conflicts. In our sample there are countries that score lowly in terms of creditor rights, but are polar opposites where culture is concerned (compare Japan and the United States). Also, culturallyproximate countries can offer varying degrees of legal protection to creditors (compare Hong Kong and Thailand). Hence our sample exhibits sizable variation in culture and creditor rights across countries which make it possible for us to test how they interact with one another to influence corporate dividend policy. Thus, in this paper we test (a) the formal agency cost of debt and equity dividend-creditor rights relationship inclusive of culture by exploring the dividend-creditor rights relationship in countries defined as either individualist or collective, and (b) the informal agency cost of equity dividendculture relationship inclusive of the agency costs of debt, by exploring the dividend-individualism relationship in strong and weak creditor rights regimes.

First, we explore the dividend-creditor rights relationship in individualist and collectivist traditions. To date tests of the agency models of dividends have been conducted by including legal variables which provide an objective assessment of the severity of the agency costs of equity and debt. These studies show that creditors demand lower dividends given weak creditor rights, and permit the status-quo to be maintained where creditor rights are strong. Therefore, under strong creditor rights we expect large (small) dividend payouts to remain in individualist (collectivist) traditions. The level of dividend payouts in individualist and collectivist traditions given weak creditor rights are not as clear. Under weak creditor rights, we hypothesize that where the relationship between corporate insiders and outsiders is harmonious in collectivist cultures, creditors may not demand lower dividends. In this instance, creditors perceive that the agency costs of debt are much lower than those suggested under the legal code, and place few if any restrictions on corporate dividend payouts. In contrast, where both culture and the law suggest high agency costs of debt, creditors are much more likely to restrict dividend payouts. This suggests that it is when creditor rights are weak that legal rights and culture come together to influence corporate dividend policy. This line of reasoning leads to our first testable hypothesis, which is that we expect that dividend payouts are sensitive to creditor rights in individualist regimes, but much less sensitive in collectivist regimes. The positive dividend-creditor rights relation espoused by Brockman and Unlu (2009) may occur in individualist traditions alone. Individualism serves to moderate the dividend creditor rights relationship resulting in a weaker or even negative dividend creditor rights relationship in collectivist traditions.

Second, the dividend-individualism literature shows that dividend payouts are largest in cultural traditions where the perceived agency costs of equity and debt are high. Dividends are an outcome of high individualism. In this paper we test the dividend-individualism relationship inclusive of the formal agency costs of debt by examining whether these culturallyrooted outcome models of dividends hold under weak creditor rights? To date the dividend-individualism relationship under weak (or strong) creditor rights has not been examined. Under strong creditor rights we expect the positive dividendindividualism relationship documented in the literature to date to be maintained. Creditors, given strong legal standing will accept the status-quo, which are large dividends in individualist cultures. The dividend-individualism relationship under weak creditor rights is not clear.

To test these assertions we use measures of individualism and creditor rights and explore how they interact with one another to influence corporate payout policy. We use a sample of 17,544 firms from 28 countries over the period from 1996 to 2007. We exploit cross-country variation in individualism and creditor rights, and in a series of pooled ordinary least squares, logit and Tobit regressions, we find support in favour of both of our hypotheses. The dividend-creditor rights relationship is positive and stronger where individualism prevails. In collectivist traditions, the relationship is weaker and sometimes negative because creditors do not demand lower dividends in collectivist regimes to compensate for weak legal standing. The positive dividend-individualism relationship is observed under strong creditor rights alone. Well-protected creditors consent to high dividends in individualist countries. Under weak creditor rights, the dividend-individualism relationship is negative. The culture-outcome model of dividends does not hold under weak creditor rights for two reasons. First, dividend payouts are much lower in individualist traditions because poorly protected creditors compel managers to pay lower dividends. Second, creditors do not demand lower dividends in collectivist cultures. The net effect is that under weak creditor rights, the dividend-individualism relationship is very often negative.

Finally, we are able to attach both statistical and economic significance to our findings. In individualist traditions, a worst-to-best change in creditor rights results in a change in dividends paid as a percentage of cash flow of 20.5 percentage points i.e., 5.4\%-25.9\%. In collectivist societies, the same change in creditor rights results in a range of dividend payouts of just $1.9 \%$ i.e. $11.3 \%-13.2 \%$. In dividend-individualism regressions, where creditor rights are strong, dividends-to-cash flow ranges from 12.3 to $13.2 \%$ across the individualism spectrum. Under weak creditor rights, a worst-to-best change in individualism results in a reduction in dividends paid from 20.4 to $5.1 \%$. All in all, our findings say that poorly-protected creditors place few 
restrictions on dividend payout in collectivist traditions, but much larger restrictions where individualism prevails. Dividend payouts are more sensitive to creditor rights than they are to culture, yet culture moderates the effect of weak creditor rights on dividend payout policy.

In summary, our findings in this paper suggest that creditors influence over corporate payout policy is influenced by legal rules and culture. When creditors rights are weak, cultural differences dictate how creditors influence dividend policy. Where the national culture is one that lends itself to individual goals and wants, creditors will not only perceive agency conflict to be severe, but will themselves pursue their own individual needs and exert their influence on firms to pay lower dividends. However, where the national culture is one that is more focused on group cohesion, even poorly-protected creditors will consider agency conflicts to be less severe and choose not to substitute their poor legal standing with lower dividends. The cultural effect is strong enough to substitute for weak legal rights. In collectivist traditions, dividend payouts are not lower under weak creditor rights, as creditors effectively view "strong" culture and weak legal rights as substitutes. The cultural effect is strong enough to moderate the effect of weak creditor rights on corporate dividend payouts.

Our paper proceeds as follows. Section two develops two testable hypotheses. This is followed by a discussion of the data and the empirical design. Section four presents and discusses our findings, while section five concludes.

\subsection{Theories and hypotheses development}

In this section we develop testable hypothesis which address how creditor rights and culture may interact with one another to influence corporate dividend payout policy. We begin by reviewing the agency cost of equity and debt inclusive models of dividends. We then review the dividend-culture literature where the focus is on the relationship between insiders and shareholders. From here, we develop and state our hypotheses.

\subsection{Agency cost of equity and debt models of dividends}

The notion that dividends can curb agency costs of equity is not new (see for example, Rozeff, 1982; Easterbrook, 1984; Jensen, 1986; Lang and Litzenberger, 1989; Gomes, 2000, to name but a few). La Porta et al. (2000) formulate two competing, but not mutually-exclusive, agency theories of dividend payout, namely the outcome and substitution models. The equityonly version of the outcome model predicts a positive relationship between the strength of shareholder rights, which can be measured at the country or firm-level, and the likelihood of paying a dividend and the dividend amount. ${ }^{1}$ Shareholders can use their legal rights to force firms to initiate a dividend in the first instance, and pay larger dividends once they ultimately decide to do so (see Mitton, 2004; Jiraporn et al., 2011; Bartram et al., 2012; Brockman and Unlu, 2009, 2011; Byrne and O'Connor, 2012; Shao et al., 2013, to name but a few who find support in favour of the outcome model).

The equity-only version of the substitution model says that firms can build "reputation capital" and substitute for poor governance/disclosure standards by establishing a history of paying large dividends over time to "convince shareholders that it will invest properly and for their benefit" (see Claessens and Yurtoglu, 2013, pp. 21; Gan et al., 2013). Once trust has been established between insiders and outsiders, these firms benefit in terms of reduced financing constraints, higher growth rates, and higher firm value (see Gan et al., 2013). Presumably financially unconstrained well-governed firms pay lower dividends. Hence, the substitution model predicts a negative relationship between legal rights/governance and corporate dividend payouts. While studies to date have found mostly in favour of the outcome model, evidence has also been offered to support the substitution model (see for example, John and Knyazeva, 2006; Officer, 2006; Jiraporn and Ning, 2006; Chae et al., 2009). Brockman and Unlu (2011) show that the substitution model prevails in countries where disclosure environments are opaque and the outcome model in countries where disclosure environments are transparent.

More recently, others have extended the equity-only versions of the outcome and substitution models to consider the agency costs of debt. Brockman and Unlu (2009) contend that dividend payouts are more sensitive to country-level creditor and not shareholder rights, suggesting that it is creditors, and not shareholders, who exert the greater influence over corporate dividend policy. Poorly protected creditors substitute their weak legal rights with lower dividends. In other words, the equity-only version of the outcome model of dividends inclusive of agency costs of debt may not hold under weak creditor rights. Shao et al. (2013) and Byrne and O'Connor (2012) show that this is in fact the case. The outcome model prevails given strong shareholder and creditor rights only, and anomalously, the substitution model prevails under weak creditor rights. The former finding suggests that where creditor legal standing is weak, creditors demand, and firms consent to lower dividends. Shao et al. (2013) perform some additional tests and demonstrate that strong creditor rights do not substitute for poor shareholder rights; dividend payouts remain low in instances where shareholder rights are weak, yet creditor rights strong.

\footnotetext{
1 La Porta et al. (2000) find that dividend payouts are an outcome of country-level shareholder rights. Mitton (2004) concludes that corporate dividend payouts are an outcome of effective corporate governance and country-level shareholder rights, and dividend payouts are largest where both country and shareholder are strong. Tse (2004) questioned the logic of using large dividends to reduce agency costs in well-governed firms, since agency conflicts and thus agency costs are likely to be low in these firms in the first instance. Dey (2008) suggests that this is not the case, since he finds that the incidence of agency conflicts is more likely in well-governed firms.
} 


\subsection{Agency costs of equity models of culture and dividend payout}

Recently it has been suggested that cultural differences may help to explain why dividend policy varies substantially across countries. Bae et al. (2012) suggest that the lack of consensus on the determinants of dividend policy may be due to the failure to consider cultural differences across countries. ${ }^{2}$ The idea that culture can help explain corporate dividend policy rests on the notion that the underlying shared beliefs and values of individuals in a society can have an influence on how corporations are managed and thus shape dividend policy. Cultural explanations for dividend policy have been offered by among others, Khambata and Liu (2006), Fidrmuc and Jacob (2010), Shao et al. (2010), and Bae et al. (2012).

Khambata and Liu (2006) use the Hofstede index to develop a measure of risk aversion (high uncertainty avoidance and long-term orientation implies higher risk aversion) and find that more risk averse managers will be less likely to pay dividends, instead preferring to retain more cash in order to minimise default risk. Fidrmuc and Jacob (2010) examine the relationship between cultural differences and dividends in forty one countries and find that cultural differences do have significant explanatory power when explaining dividend payouts. Using the Hofstede index, they show that high individualism, low power distance, and low uncertainty avoidance are significantly associated with higher dividend payouts, even more so after accounting for the strength of shareholder rights.

Bae et al. (2012) argue that national culture can shape a firm's dividend strategy because people's subjective perceptions on the benefit of financial flexibility are contingent on the country's culture, and in turn, financial flexibility influences dividend policy. They find that culture, measured by Hofstede's uncertainty avoidance, masculinity, and long term orientation are significantly and negatively related to dividend levels of a firm, even after controlling for other firm and country-specific factors. Further, they find that the association between national culture and the dividend level of a firm varies with the level of shareholder protection. They show in cultures where agency conflicts are perceived to be more severe, dividend payouts are even larger when shareholders are well protected. They show not only that national culture and shareholder protection individually affect dividend payout policy, but also explain how national culture and corporate governance are interrelated in influencing dividend policy. Shao et al. (2010) use Schwartz's national culture dimensions. Focusing on the shareholdermanagement relationship, they find that conservatism is positively and significantly related to corporate dividend payouts while mastery is negatively and significantly related to corporate dividend payouts.

These aforementioned papers all perform tests of the dividend-culture relationship where only the agency costs of equity are considered. For example, the relationship between dividend payout and individualism is positive because shareholders accept low dividends payouts in collectivist cultures but demand large dividends in individualist cultures to compensate for high agency costs of equity. Shao et al. (2010) acknowledge that they have not taken the shareholder-debtholder relationship into consideration in their analysis and suggest this as an area that warrants further research. In this paper we do just that by examining the relationship between individualism, creditor rights, and dividend policy. We test (a) the equity and debt inclusive dividend-creditor rights relationship in collectivist and individualist traditions and (b) the agency cost of equity cultural models of dividends inclusive of the agency costs of debt by testing the dividend-individualism relationship in strong and weak creditor rights regimes. In the next section we develop and state these hypotheses formally.

\subsection{Hypotheses}

In this section we develop our hypotheses together with a description of Hofstede's individualism measure which is the culture measure we employ in this paper. Hofstede defines culture as "the collective programming of the mind distinguishing the members of one group or category of people from another". Culture can seem to distinguish one group/society from another based on a certain set of values, beliefs and behaviours that are shared within a group that makes that group unique and distinguishable from another. The cultural index developed by Hofstede identifies five cultural dimensions, namely, individualism, power distance, uncertainty avoidance, masculinity, and long-term orientation. We use individualism to develop our hypotheses.

\subsection{Individualism, collectivism and the strength of creditor rights}

In societies when individualism is high the focus is on the pursuit of individual happiness, rather than the pursuit of the collective goal. In collectivist traditions individuals do not seek to maximize their own private benefits, but adjust their behaviour so that their behaviour and beliefs are in line with those of a wider group of other stakeholders, a group in which individuals value membership. These alternative value systems have important implications for the perceived severity of agency conflicts and, importantly for this study, for the potential role played by corporate dividend payouts in alleviating such agency concerns.

First, in countries with an individualist tradition, investors are cognisant of the fact that insiders are likely to pursue their own self-interests and may engage in the consumption of private benefits. As a result, agency conflicts are expected to be

\footnotetext{
${ }^{2}$ Cultural explanations have been offered for a wide range of financial issues such as how financial systems evolve (see Kwok and Tadesse, 2006), the capital structure of a firm (see Chui et al., 2002), corporate debt maturity (see Zheng et al., 2012), the corporate governance system (see Griffin et al., 2014), and corporate hedging (see Lievenbruck and Schmid, 2014).
} 
Table 1

Hypotheses relating national culture and creditor rights to payout policy. Creditor rights

\begin{tabular}{|c|c|c|c|}
\hline National culture & Strong creditor rights & Weak creditor rights & Hypothesis 2 \\
\hline Collectivism & Low payout & $?$ & Dividend payouts are positively related to individualism where \\
\hline Individualism & $\begin{array}{l}\text { High payout } \\
\text { Hypothesis } 1\end{array}$ & Low payout & $\begin{array}{l}\text { creditor rights are strong. The relationship between dividend payout } \\
\text { and individualism is ambiguous where creditor rights are weak }\end{array}$ \\
\hline & \multicolumn{3}{|c|}{$\begin{array}{l}\text { Dividend payouts are positively related to the strength of creditor rights in } \\
\text { individualist cultural traditions. In collectivist traditions, the relationship } \\
\text { between creditor rights and dividend payout is ambiguous }\end{array}$} \\
\hline
\end{tabular}

severe, and because of this, shareholders demand large dividend payouts from firms as a consequence. Firms cater to the desire for larger dividends since there are many reasons to suggest that doing so is also in their own best interests (see Faccio et al., 2001). The result is that in countries that score high in terms of individualism, dividend payouts are large (see Fidrmuc and Jacob, 2010).

Dividend payouts are much lower in countries where collectivism prevails. Here the perception is that agency conflicts are less severe, as in these countries insiders are much less likely to consume private benefits. Instead, insiders behave in a manner consistent with the pursuit of an overall group goal, whereby the decisions made by corporate insiders benefit both insiders and outsiders alike. Where collectivism prevails, shareholders are prepared to accept lower dividend payouts.

In this paper, we are interested in how individualism and creditor rights interact to influence corporate dividend payouts. We believe that the answer lies in how creditors perceive the extent of agency conflicts within countries. The perceived extent of agency conflicts which is shaped by culture can be in marked contrast to the level of agency costs implied by the strength of legal rights. Hence, culture and creditor rights can complement one another (e.g. high creditor rights in collectivist countries and low creditor rights in individualist countries), but can also substitute for one another. We turn to a discussion of these possibilities and the implications for the relationships between culture and dividend payout, and creditor rights and dividend payout, respectively.

On the one hand, since insiders are much less likely to pursue their own best interests at the expense of creditors in collectivist traditions, dividend payouts are likely to be largely insensitive to the strength of creditor rights in these countries. Where creditor rights are strong, creditors are likely to accept the status quo, which are low dividend payouts in collectivist traditions. Furthermore, and as demonstrated by Shao et al. (2013), creditors will not use their strong legal standing to pressure firms to pay larger dividends, when there is no pressure from elsewhere to do so. In this paper, we hypothesise that strong creditor rights will not result in large dividends in collectivist traditions where low dividends are the cultural norm. Also, we hypothesise that creditors are unlikely to affect the cultural norm in collectivist countries by demanding even lower dividends where their legal rights are weak, because in collectivist countries the interests of large creditors are much more likely to be protected, hence no longer necessitating the need for restricted dividends to substitute for poor creditor rights.

In summary, since creditors are likely to accept the cultural norm for low dividend payouts in collectivist countries where creditor rights are strong, and are unlikely to demand even lower dividends given weak creditor rights, we conclude that the direction of the relationship between dividend payout and creditor rights in collectivist traditions is ambiguous, but we expect that the strength of the relationship is likely to be weak.

In individualist cultures we hypothesize that the relationship between dividend payout and creditor rights is less ambiguous. Creditors will permit large dividend payouts in individualist countries where creditor rights are strong, but not so where their legal rights are weak. Given poor legal standing, creditors will demand lower dividend payouts in individualist traditions. An alternative view is that poorly-protected creditors may not seek lower dividend payouts in individualist societies because large dividend payouts serve to reduce agency conflicts in these regimes the first instance. If this is the case, we would expect to observe that dividends are positively related to individualism across the creditor rights spectrum. While we expect that creditors are likely to place restrictions in individualist societies given weak creditor rights, the possibility remains that they may not.

In summary we expect to observe the following. First, dividend-creditor rights relationship is positive in individualist countries. Second, the dividend-individualism relationship is positive where creditor rights are strong. Third, where creditor rights are weak, creditors are much more likely to demand lower dividends in individualist countries, than they are in collectivist countries. However, since dividend payouts are already low in collectivist traditions, the relationship between dividend payout and individualism is ambiguous. These arguments allow us to state our first and second testable hypotheses, which are summarized in Table 1:

Hypothesis 1. Dividend payouts are positively related to the strength of creditor rights in individualist cultural traditions. In collectivist traditions, the relationship between creditor rights and dividend payout is ambiguous.

Hypothesis 2. Dividend payouts are positively related to individualism where creditor rights are strong. The relationship between dividend payout and individualism is ambiguous where creditor rights are weak. 
Table 2

Construction of the sample.

\begin{tabular}{ll}
\hline Number of firms & Description \\
\hline 36,089 & Worldscope coverage of firms (active and inactive) in forty-five countries, between 1996 and 2007 \\
-1056 & Firms in mandatory dividend countries \\
-2789 & Missing dividend data, negative dividends, sales, cash flow, earnings, assets \\
-5474 & Financial and utility firms \\
-3644 & Missing control variables \\
-5582 & Firms with less than three firm-year observations \\
17,544 & Sample \\
\hline
\end{tabular}

\section{Data}

To test our hypotheses we estimate a series of pooled ordinary least squares, logit and Tobit regressions. Our approach differs from previous studies in that we examine the joint effect of creditor rights and individualism on dividend policy. To explore these issues, we source a sample of 17,544 firms from 28 countries. Table 2 summarizes the construction of our sample. Initially we sourced 36,089 firms from forty-five countries. We exclude firms from countries with mandatory dividend policies i.e., Brazil, Chile, Colombia, Greece, and Venezuela, resulting in a loss of 1056 firms. We lose a further 2789 firms with missing or abnormal data i.e. firms with negative net income, negative total assets, and negative cash flow, and 3644 firms with insufficient control variable coverage (including the country-level disclosure measure). As is common in dividend payout studies we exclude financial and utility firms which further reduce our sample by 5474 firms, resulting in a final sample of 17,544 firms. This sample covers the years from 1996 to $2007 .^{3}$ We source the creditor rights measure from Djankov et al. (2007). Creditor rights ranges from a low of zero to a high of four, with higher values suggesting strong creditor protection. We use creditor rights for the year $2002 .{ }^{4}$ We employ the cultural dimension of individualism which we source from Hofstede (1980, 2001). Individualism captures the extent of individualism (high values of this measure) and collectivism (low values) in a society.

Table 3 presents summary statistics for dividend payout, creditor rights and individualism. The United States (4712 firms), Japan (3333), and the United Kingdom (9702) contribute the largest number of firms, while Argentina (47), Ireland (46) and Austria (54) provide the fewest. Sample-bias in favour of firms from the United States, Japan and the United Kingdom is common in these types of studies.

We use five dividend payout measures, namely dividends-to-cash flow, dividends-to-earnings, dividends-to-assets, dividends-to-sales, and dividend payer. Dividends are total regular dividends paid to common shareholders, scaled by cash flow, earnings, assets, or sales, as indicated. Payer equals 1 if the firm pays a dividend in year t and zero otherwise. Table 3 outlines median payer by country. Payer is the proportion of firms in each country which pay a dividend and is calculated as follows. For each country, payer is calculated on a yearly basis from 1996 to 2007, and we report the median payer for each country over this time interval. ${ }^{5}$ The amount paid in dividends varies greatly across countries. Dividend amounts are large in New Zealand (dividends-to-cash flow is 0.38), yet much smaller in Canada (dividends-to-cash flow is 0.05) and the United States (dividends-to-cash flow is 0.04). Payer exhibits similar variation across countries. The median firm in the United States does not pay a dividend, while the proportion of dividend payers in India is 0.94 .

Table 3 also reports creditor rights and individualism for each country. Creditor rights are strong in Hong Kong, New Zealand and the United Kingdom yet weak in Mexico and France. The United States, Australia, and the United Kingdom are individualist societies while Thailand, Singapore and Korea are collective in nature. Crucial to our analysis is that across countries of equal cultural standing (creditor rights), there exists sizable differences in creditor right protection (individualism). Australia and the United States score almost identically in terms of individualism, but are very different in how their legal system protected creditor interests. Argentina, a largely collective society, and the United States, individualist, provide the same level of creditor rights. Creditor rights are negatively correlated (unreported) with individualism, which suggest that with some exceptions, creditor rights are stronger in collectivist (low individualism) countries. For example, largely collective countries such as Hong Kong, the Netherlands and Korea (Republic) score highly in terms of creditor rights while the U.S., which is considered individualist, does not. The exceptions are provided by among others, Australia and Mexico. Australia, classified as individualist, provides stringent protection for creditors. Mexico, a collectivist country, does not.

Panel B of Table 3 summarizes our five dividend payout measures. The average firm pays out just over ten percent of its cash flow as a dividend, yet the median firm pays no dividend at all. Panel $\mathrm{C}$ outlines the number of firm observations by year. The number of observations varies across years, ranging from 5812 in 1996 to a high of 14,250 in 2005.

\footnotetext{
${ }^{3}$ In a series robustness tests which follow in Tables 7 and 8 we show that our results are robust to increasing the sample size and extending the sample period. We discuss these issues later in the paper.

${ }^{4}$ In a series of unreported tests we find that our findings are unaffected when we use creditor rights for different years.

${ }^{5}$ This is the same approach used by DeAngelo et al. (2006) to calculate payer.
} 
Table 3

Sample description.

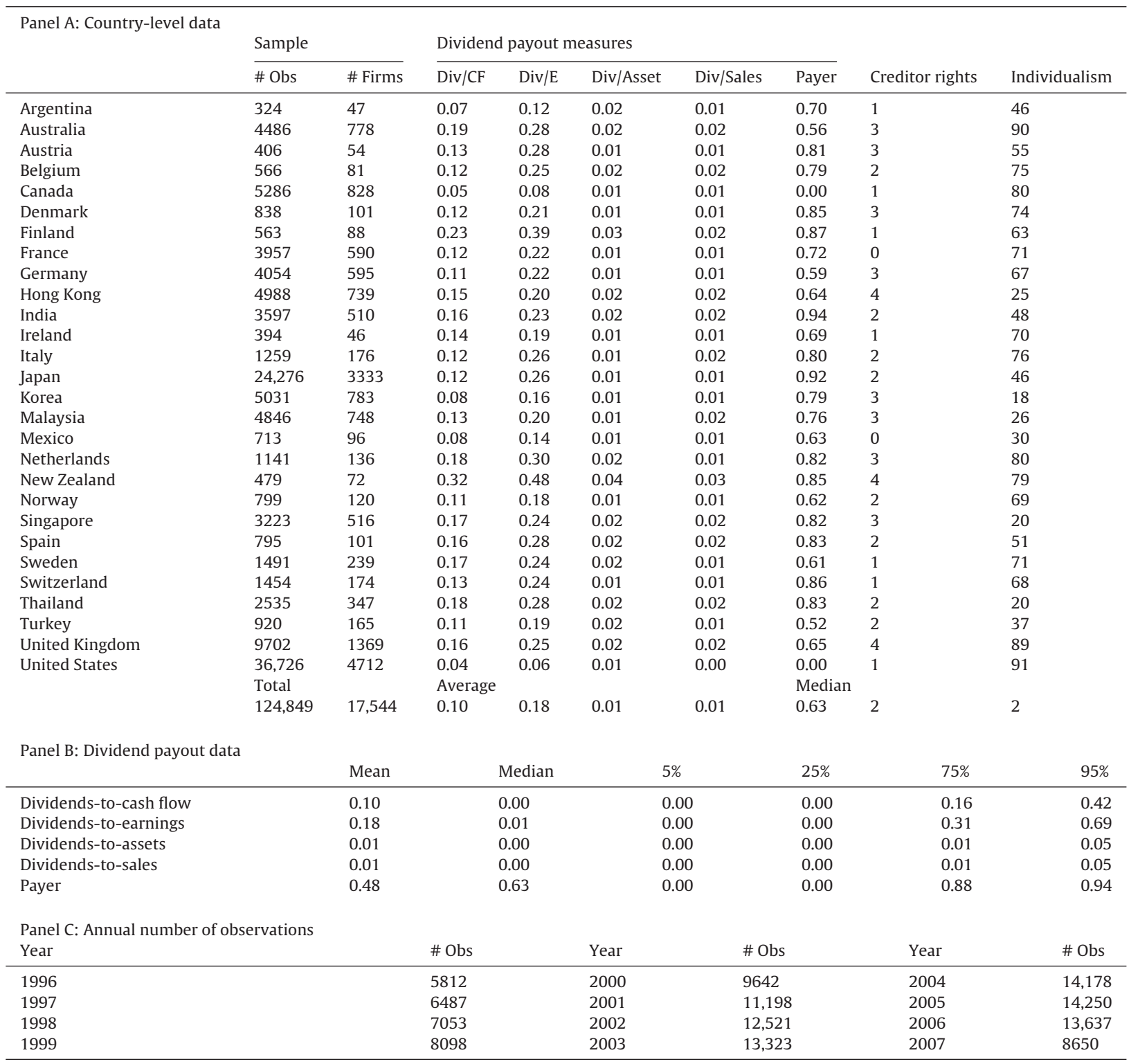

This table reports summary statistics for our sample of firms. Panel A reports summary statistics by country. \# Obs is the number of firm-year observations, and \# Firms, the number of firms in each country. Average dividend payout is reported for each country. Dividend payout is dividends-to-cash flow (Div/CF), dividends-to-earnings (Div/E), dividends-to-assets (Div/Assets), and dividends-to-sales (Div/Sales), as indicated. Payer is the proportion of firms in each country which pay a dividend. Payer is first calculated on a yearly basis from 1996 to 2007, and we report the median payer for each country over this time interval. Creditor rights are from Djankov et al. (2007) and correspond to values in 2002. Individualism is from Hofstede (2001). Dividend payout data is from Worldscope. Panel B reports summary statistics for each dividend payout measure. Panel C reports the number of observations by year. The sample period is $1996-2007$.

\section{Empirical findings}

\subsection{Univariate comparions}

We begin by presenting summary payout statistics by level of individualism and creditor rights. Consider Table 4 . Here we divide our sample of firms as follows: firms are in countries with high (low) creditor rights if their country level score for creditor rights is equal to or greater than (less than) the (country) sample median, which is 2 . Firms are in countries with high (low) individualism, if their country level individualism score is greater than (or less than) the (country) sample median, which is 68 . This results in four distinct individualism/creditor rights regimes, namely (1) strong creditor rights/individualist, 
Univariate comparisons and initial tests of hypotheses 1 and 2.

\begin{tabular}{|c|c|c|c|c|c|c|}
\hline & \multicolumn{6}{|c|}{ Test of hypothesis 1} \\
\hline & \multicolumn{6}{|c|}{ The relationship between dividend payout and creditor rights under individualist and collectivist cultural traditions } \\
\hline & \multicolumn{3}{|c|}{ High individualism } & \multicolumn{3}{|c|}{ Low individualism (collectivism) } \\
\hline & \multicolumn{3}{|c|}{ Strong versus weak creditor rights } & \multicolumn{3}{|c|}{ Strong versus weak creditor rights } \\
\hline & $\begin{array}{l}\text { Strong Creditor } \\
\text { Rights }(n=5)\end{array}$ & $\begin{array}{l}\text { Weak Creditor } \\
\text { Rights }(n=8)\end{array}$ & $\begin{array}{l}\text { Difference: strong less } \\
\text { weak (Relationship) }\end{array}$ & $\begin{array}{l}\text { Strong Creditor } \\
\text { Rights }(n=6)\end{array}$ & $\begin{array}{l}\text { Weak Creditor } \\
\text { Rights }(n=10)\end{array}$ & $\begin{array}{l}\text { Difference: strong less } \\
\text { weak (Relationship) }\end{array}$ \\
\hline Div-Cash flow & 0.13 & 0.09 & $0.04^{* * *}$ (Positive) & 0.05 & 0.12 & $(0.07)^{* * *}$ (Negative) \\
\hline Div-Earnings & 0.22 & 0.19 & $0.03^{* * *}$ (Positive) & 0.12 & 0.22 & $(0.10)^{* * *}$ (Negative) \\
\hline Div-Payer & 0.82 & 0.66 & $0.16^{* * *}$ (Positive) & 0.78 & 0.83 & $(0.05)^{* * *}$ (Negative) \\
\hline
\end{tabular}

Test of hypothesis 2

The relationship between dividend payout and individualism under strong and weak creditor rights

\begin{tabular}{|c|c|c|c|c|c|c|}
\hline & \multicolumn{3}{|l|}{ Strong creditor rights } & \multicolumn{3}{|l|}{ Weak creditor rights } \\
\hline & \multicolumn{3}{|c|}{ High versus low individualism (collectivism) } & \multicolumn{3}{|c|}{ High versus low individualism (collectivism) } \\
\hline & $\begin{array}{l}\text { High Individualism } \\
(\mathrm{n}=5)\end{array}$ & $\begin{array}{l}\text { Low Individualism } \\
\text { (Collectivism) }(n=6)\end{array}$ & $\begin{array}{l}\text { Difference: high less } \\
\text { low (Relationship) }\end{array}$ & $\begin{array}{l}\text { High Individualism } \\
(\mathrm{n}=8)\end{array}$ & $\begin{array}{l}\text { Low Individualism } \\
(\mathrm{n}=10)\end{array}$ & $\begin{array}{l}\text { Difference: high less } \\
\text { low (Relationship) }\end{array}$ \\
\hline Div-Cash flow & 0.13 & 0.05 & $0.08^{* * *}$ (Positive) & 0.09 & 0.12 & $(0.03)^{* * *}$ (Negative) \\
\hline Div-Earnings & 0.22 & 0.12 & $0.10^{* * *}$ (Positive) & 0.19 & 0.22 & $(0.03)^{* * *}$ (Negative) \\
\hline Div-Payer & 0.82 & 0.78 & $0.04^{* * *}$ (Positive) & 0.66 & 0.83 & $(0.17)^{* * *}$ (Negative) \\
\hline
\end{tabular}

This table reports summary median payout statistics by level of culture and creditor rights. Firms are domiciled in countries with high (low) creditor rights (culture) if their country level score for creditor rights (culture) is equal to or greater (less than) the sample median. To calculate median payout, we calculate the median dividend payout for each country in each regime, and report the median of the median payouts. The median payouts for each country are reported in Appendix A. The median values of creditor rights and individualism are based on the number of countries in the sample. Dividend payout is dividends-to-cash flow (Div-Cash flow), dividends-to-earnings (Div-Earnings), or payer (Div-Payer), as indicated. Payer is the median proportion of firms in each regime which pay a dividend. Creditor rights are from Djankov et al. (2007), and culture (individualism) is from Hofstede (2001). Asterisks denote significance of z-tests of the equality of medians, where *** denote significance at the $1 \%$ level. Appendix A provides median payout data for counties classified into one of the four culture/creditor rights regimes.

(2) weak creditor rights/individualist, (3) strong creditor rights/collectivist, and (4) weak creditor rights/collectivist. There are $5,8,6$, and 9 countries in each of these four regimes, respectively.

Table 4 reports median dividend payouts for each regime. The median dividend payout figure reported for each regime is the median of the individual country median payouts. ${ }^{6}$ The figures reported provide unconditional support in favour of our hypotheses, while also revealing the possible direction of the relationships that we earlier deemed ambiguous. In the top rows of Table 4, we test hypothesis 1 , while an initial test of hypothesis 2 is provided underneath.

First, dividend payouts are larger in individualist traditions under strong creditor rights. Using dividends-to-cash flow, median dividend payout is 0.13 under strong creditor rights and 0.09 under weak creditor rights. The proportion of firms which pay a dividend is also larger under strong creditor rights (compare 0.82 under strong creditor rights to 0.66 under weak creditor rights). Creditors appear to restrict dividend payouts in individualist cultures where their legal rights are weak. In contrast, we observe no such restriction in collectivist countries. Rather, where creditor rights are weak, dividend payouts are actually larger under weak creditor rights suggesting a negative relation between dividend payout and creditor rights in collectivist regimes.

These summary measures provide initial support for hypothesis 1 , since we observe that dividend payouts are positively related to creditor rights, but in individualist cultures alone. In collectivist societies the relationship between dividend payout and creditor rights is negative. Note that our main hypotheses do not rely on the prevalence of a negative relationship between dividend payout and creditor rights in collectivist countries. Rather, they rest on identifying individualism having a moderating effect on the creditor rights dividend payout relationship in collectivist countries. Notwithstanding the usual caveats, these simple comparisons do suggest that culture may serve to moderate the dividend-creditor rights relationship.

The bottom rows of Table 4 also provide support in favour of hypothesis 2 . Here the positive relationship between dividend payout and individualism, documented in the literature to date, manifests only under strong creditor rights. For example, under strong creditor rights, dividends-to-cash flow is 0.13 in individualist societies and 0.05 in collectivist societies. Where creditor rights are weak, the direction of the aforementioned relationship is reversed; dividend payout is negatively related to individualism under weak creditor rights. Under weak creditor rights, dividend payouts are larger in collectivist societies.

\footnotetext{
${ }^{6}$ Appendix A shows the median dividend payout for each country classified according to each creditor rights/culture regime. We also report an average of the median dividend payouts, and the median dividend payouts for each regime after excluding firms from the U.K., U.S., and Japan.
} 
Table 5

Dividend payout, creditor rights and culture.

\begin{tabular}{|c|c|c|c|}
\hline & \multicolumn{3}{|l|}{ Panel A } \\
\hline & Dividends-to-cash flow & Dividends-to-earnings & Payer \\
\hline Creditor rights & $0.014^{* * *}(11.12)$ & $0.010^{* * *}(4.61)$ & $-0.019^{* * *}(6.92)$ \\
\hline Individualism & $-0.001^{* * *}(11.25)$ & $-0.001^{* * *}(9.84)$ & $-0.002^{* * *}(11.98)$ \\
\hline Disclosure & $-0.039^{* * *}(8.61)$ & $-0.060^{* * *}(9.27)$ & $-0.101^{* * *}(9.97)$ \\
\hline Disclosure $^{2}$ & $0.0003^{* * *}(9.20)$ & $0.0004^{* * *}(9.53)$ & $0.001^{* * *}(9.98)$ \\
\hline Shareholder rights & $0.010^{* * *}(4.04)$ & $0.027^{* * *}(9.36)$ & $0.114^{* * *}(22.89)$ \\
\hline Size & $0.014^{* * *}(29.65)$ & $0.028^{* * *}(40.79)$ & $0.071^{* * *}(36.65)$ \\
\hline Growth & $-0.016^{* * *}(15.15)$ & $-0.021^{* * *}(14.62)$ & $-0.033^{* * *}(7.50)$ \\
\hline Leverage & $-0.082^{* * *}(28.92)$ & $-0.097^{* * *}(22.33)$ & $-0.368^{* * *}(27.88)$ \\
\hline Profitability & $0.028^{* * *}(15.91)$ & $0.022^{* * *}(9.21)$ & $1.794^{* * *}(81.71)$ \\
\hline Tobin's $q$ & $0.010^{* * *}(11.64)$ & $0.001(0.03)$ & $-0.074^{* * *}(32.69)$ \\
\hline Dividend premium & $0.072^{* * *}(11.81)$ & $0.078^{* * *}(8.69)$ & $0.044^{* * *}(3.22)$ \\
\hline Industry and time dummies & Included & Included & Included \\
\hline \# Observations & 124,849 & 124,849 & 124,849 \\
\hline \multirow[t]{2}{*}{ R-Squared } & 0.155 & 0.163 & 0.413 \\
\hline & \multicolumn{3}{|c|}{ Economic significance of in-sample predictions for payout ratios (\%) } \\
\hline Creditor rights & $7.3-13.0$ & $15.1-18.5$ & $0.51-0.37$ \\
\hline \multirow[t]{3}{*}{ Individualism } & $12.3-8.4$ & $21.0-14.0$ & $0.65-0.40$ \\
\hline & \multicolumn{3}{|c|}{ Economic significance of in-sample predictions using alternative payout ratios (\%) } \\
\hline & Dividends-to-assets (\%) & \multicolumn{2}{|c|}{ Dividends-to-sales (\%) } \\
\hline Creditor rights & $0.45-1.46$ & \multicolumn{2}{|l|}{$0.42-1.28$} \\
\hline Individualism & $1.16-0.53$ & \multicolumn{2}{|l|}{$1.17-0.43$} \\
\hline
\end{tabular}

\subsection{Multivariate regressions}

Next we carry out a series of regressions to test our hypotheses. In all regressions, we control for firm size, firm growth, leverage, firm profitability, and growth opportunities. We also include a measure for dividend premium which captures investor's appetite for dividend paying stocks. ${ }^{7}$ A priori, we expect the estimated coefficient on this variable to be positive (see Baker and Wurgler, 2004). These variables are defined in Appendix B. All firm-level variables are sourced from Worldscope.

We first consider the relationships between creditor rights and dividend payout, and individualism and dividend payout, respectively. We employ dividends-to-cash flow, dividends-to-earnings, and payer as our payout measures, as indicated, and include creditor rights, individualism, and firm-level controls, with time and industry dummies in all regressions. The results from pooled ordinary least squares and logit regressions are presented in Table 5. In all regressions, the standard errors are clustered by firm (see Petersen, 2009). The goal of Table 5 is to see if we can replicate the findings from the previous literature. Using creditor rights we can, using individualism, we cannot.

The first observation we make is that creditor rights matter. The estimated coefficient on creditor rights is positive and is statistically significant at the $1 \%$ level. Interestingly, the estimated coefficient on creditor rights is negative when payer is the dependent variable. Next, we consider individualism. Previous studies find a positive relationship between individualism and dividend payout. In our analysis, we find the exact opposite. The estimated coefficients for individualism are negative. We believe that this is because the majority of firms in our sample are domiciled in countries where creditor rights are weak and the coefficients we observe are of the sign we would expect for individualism in countries with poor creditor rights, if our hypotheses are correct. The coefficient on individualism is negative and significant at the $1 \%$ level, suggesting that dividend payout and the likelihood of paying a dividend is lower for firms in individualist countries. This is in contrast to the findings of Fidrmuc and Jacob (2010) and others. ${ }^{8}$

\footnotetext{
7 Dividend premium is measured on an annual basis for each country. It is computed as the ratio of the average market-to-book ratio of dividend paying firms to the average market-to-book ratio of non-paying firms. The average dividend premium for each country is reported in Appendix C. They suggest that, all else equal, the greater appetite for dividend paying stocks is in Argentina and Mexico.

8 Fidrmuc and Jacob, 2010 (2010, pp. 331)Fidrmuc and Jacob, 2010Fidrmuc and Jacob, 2010 (2010, pp. 331) find a positive dividend-individualism relationship using dividends-to-earnings, yet a negative relationship using dividends-to-cash flow. On closer inspection of their data, they conclude that
} 
The control variables are almost always statistically significant and of the expected sign. We follow Brockman and Unlu (2011) and include the $\mathrm{CIFAR}^{9}$ measure of country transparency (its level and square) in all regressions, and like them we refer to this variable as "Disclosure" in all regressions. ${ }^{10}$ We find similar to them in all regressions. The estimated coefficient is negative for the level of disclosure and always positive on the squared disclosure term. These coefficient estimates suggest that the agency substitution model prevails in countries where disclosure is minimal and the agency outcome model of dividends is observed where disclosure levels are high. The sign on our remaining control variables are in line with what we expect to find. The dividend amount tends to be greater when firms are large and profitable. In contrast, growth firms with sizable growth opportunities pay either little or small dividends. The collective findings for size, profitability, growth and growth opportunities are in line with the life-cycle model of dividends (see DeAngelo et al., 2006; Denis and Osobov, 2008; Brockman and Unlu, 2011; Bulan and Subramanian, 2009, for a review of the life-cycle model). Leverage and dividend payout are negatively related since in firms where dividends are large, there is no requirement to employ debt in a bonding role. Finally, the coefficient estimate on the dividend premium variable is positive. With the exception of growth opportunities, the control variables are of the same sign in the logit regressions.

The bottom rows of Table 5 shed light on the economic significance of creditor rights and individualism by outlining the predicted dividend payout amounts. We report the predicted payout as creditor rights changes from zero to four. For individualism, the predicted payouts are calculated by allowing individualism to change from an average of the bottom two individualism scores to an average of the top two scores. We adopt this approach because few countries score the same in terms of individualism, and as a consequence we do not want our predicted payouts to correspond to any one single country. The predicted payouts are calculated by evaluating all independent variables at their sample medians, for the year 2005 and for industrial firms. All else equal, as creditor rights increases from zero to four, dividends as a percentage of cash flow increases from $7.3 \%$ to $13 \%$. In relative terms this amounts to a $78 \%$ increase in the dividend amount.

A min-to-max change in individualism results in a fall in dividends-to-cash flow from $12.3 \%$ to $8.4 \%$, or a relative change in payout of almost $32 \%$. Alternatively, a max-to-min change in individualism results in a $46.4 \%$ increase in dividend payout in relative terms. This is in stark contrast to the predicted payouts outlined by Fidrmuc and Jacob (2010, pp. 327). They show that "high individualism results in dividend-to-earnings ratios that are on average $18 \%$ higher compared to collectivist countries".

We also present estimates of the predicted payouts using dividends-to-assets (\%) and dividends-to-sales (\%) so that we can make comparisons between our findings and the findings of others. Brockman and Unlu (2009) show that dividends-tosales (\%) changes from $0.78 \%$ to $1.98 \%$ (or a 2.5 fold increase) given a worst-to-best change in creditor rights. We document a change in dividends-to-sales (\%) from $0.42 \%$ to $1.28 \%$, or a 3.05 fold increase resulting from the same change in creditor rights. All in all, these estimates suggest that creditor rights and individualism exert both a sizable statistical and economically significant effect on the size and likelihood of corporate dividend payouts. The predicted payouts suggest that corporate dividend payouts are most sensitive to changes in creditor rights than they are to individualism.

We now explore our hypotheses further. To do so we run two separate regressions. First, we divide our sample into individualist and collectivist regimes and explore the dividend-creditor rights in each regime. If our hypotheses are correct, then a priori, we would expect to find that dividend payout is positively related to the strength of creditor rights in individualist cultures. The relationship between dividend payout and creditor rights in collectivist societies is ambiguous. Our findings from these set of tests are presented in Panel A of Table 6.

Our second test approach involves dividing our sample into strong and weak creditor rights sub-samples, and estimate dividend payout-individualism regressions in each creditor rights regime. A priori, we expect to find a positive relationship between dividend payout and individualism under strong creditor rights alone. Where creditor rights are weak, the nature of the relationship is much less obvious, and thus ambiguous. The results are presented in Panel B of Table 6. Byrne and O'Connor (2012) and Shao et al. (2013) adopt similar empirical approaches.

Consistent with hypothesis 1 , the coefficient estimate for creditor rights is positive $\left(0.051^{* * *}\right.$ employing dividends-to-cash flow) in individualist countries and is statistically significant. It is also positive and statistically significant for collectivist countries, yet it is much lower $\left(0.010^{* * *}\right.$ using dividends-to-cash flows), and is thus in line with our prior expectations. The difference in the slope coefficients on the creditor rights variable is largely supportive of hypothesis 1 . In individualist societies, creditors demand lower dividends where creditor rights are weak, but tolerate larger dividend payouts where their legal rights are strong. In collectivist traditions, dividend payouts are broadly similar across the creditor right spectrum. The relationship between dividend payout and creditor rights is much flatter in collectivist regimes. Using dividends-toearnings and payer, we again find support in favour of hypotheses 1 , since it is only in individualist cultures that we observe a significantly positive relationship between dividend payout and creditor rights. Interestingly, in countries where collectivism

the negative dividend-individualism relationship using dividends-to-cash flow is "driven by observations of relatively high dividend-to-cash flow ratios for the lowest quartile of individualism scores in our sample" and the relationship is positive from the second to fourth quartiles of individualism. We explore our data in the same manner and do not believe that our findings are governed by (abnormally) large dividend payouts in collectivist regimes.

9 The index is created by examining and rating companies' annual reports for their inclusion and exclusion of 85 items and ranges from 0 to 100 with 100 as the highest standard.

10 In a set of robustness tests which follow (see Tables 7 and 8), we show that our findings remain qualitatively the same when we use the revised antidirector rights measure in place of disclosure. Also, our conclusions remain unchanged when we simultaneously include disclosure and the anti-director rights index in the same regressions. This analysis is available from the corresponding author upon request. 


\section{Table 6}

Regression based tests of hypothesis 1 and 2 .

Panel A: Hypothesis 1 “Dividend payout-creditor rights" regressions in individualist (high individualism) and collectivist (low individualism) traditions

\begin{tabular}{|c|c|c|c|c|c|c|}
\hline & \multicolumn{2}{|c|}{ Dividends-to-cash flow } & \multicolumn{2}{|c|}{ Dividends-to-earnings } & \multicolumn{2}{|l|}{ Payer } \\
\hline & Individualism & Collectivism & Individualism & Collectivism & Individualism & Collectivism \\
\hline Creditor rights & $0.051^{* * *}(18.01)$ & $0.010^{* * *}(3.28)$ & $0.074^{* * *}(19.23)$ & $-0.013^{* * *}(5.41)$ & $0.016^{* * *}(12.23)$ & $-0.114^{* * *}(19.14)$ \\
\hline Controls, industry and time dummies & Included & Included & Included & Included & Included & Included \\
\hline \# Observations & 67,124 & 57,725 & 67,124 & 57,725 & 67,124 & 57,725 \\
\hline R-Squared & 0.236 & 0.140 & 0.261 & 0.110 & 0.464 & 0.403 \\
\hline Creditor rights range & 0 to 4 & 0 to 4 & 0 to 4 & 0 to 4 & 0 to 4 & 0 to 4 \\
\hline Predicted payout by creditor rights & $5.4-25.9$ & $11.3-13.2$ & $10.3-40.4$ & $26.3-21.1$ & $0.33-0.89$ & $0.90-0.55$ \\
\hline Predicted dividend-to-assets (\%) & $0.8-2.8$ & $0.5-1.3$ & & & & \\
\hline Predicted dividend-to-sales (\%) & $0.7-2.1$ & $0.4-1.1$ & & & & \\
\hline
\end{tabular}

Panel B: Hypothesis 2 “Dividend payout-individualism” regressions in strong (high creditor rights) and weak creditor rights (low creditor rights) countries

\begin{tabular}{|c|c|c|c|c|c|c|}
\hline & \multicolumn{2}{|c|}{ Dividends-to-cash flow } & \multicolumn{2}{|c|}{ Dividends-to-earnings } & \multicolumn{2}{|l|}{ Payer } \\
\hline & $\begin{array}{l}\text { Strong Creditor } \\
\text { rights }\end{array}$ & $\begin{array}{l}\text { Weak Creditor } \\
\text { rights }\end{array}$ & $\begin{array}{l}\text { Strong Creditor } \\
\text { rights }\end{array}$ & $\begin{array}{l}\text { Weak Creditor } \\
\text { rights }\end{array}$ & $\begin{array}{l}\text { Strong Creditor } \\
\text { rights }\end{array}$ & $\begin{array}{l}\text { Weak Creditor } \\
\text { rights }\end{array}$ \\
\hline Individualism & $0.001 *(1.81)$ & $-0.002^{* * *}(21.28)$ & $0.013^{*}(1.72)$ & $-0.004^{* * *}(25.93)$ & $-0.002^{* * *}(4.46)$ & $-0.004^{* * *}(19.22)$ \\
\hline Controls, industry and time dummies & Included & Included & Included & Included & Included & Included \\
\hline \# Observations & 39,194 & 85,655 & 39,194 & 85,655 & 39,194 & 85,655 \\
\hline R-Squared & 0.192 & 0.179 & 0.189 & 0.224 & 0.444 & 0.451 \\
\hline Individualism range & $18-90$ & $20-91$ & 18 to 90 & 20-91 & $18-90$ & 20-91 \\
\hline Predicted payout by individualism & $12.3-13.2$ & $20.4-5.1$ & $24.0-25.4$ & $37.7-8.7$ & $0.81-0.63$ & $0.92-0.28$ \\
\hline Predicted dividend-to-assets (\%) & $0.9-1.1$ & $1.9-0.4$ & & & & \\
\hline Predicted dividend-to-sales (\%) & $1.3-1.4$ & $1.6-0.4$ & & & & \\
\hline
\end{tabular}

This table reports coefficient estimates from pooled ordinary least squares and logit regressions with t-stats adjusted for clustering at the firm level presented underneath in parenthesis. The sample period is 1996-2007. The dependent variable is dividends-to-cash flow, dividends-to-earnings, or payer, as indicated. The top panel presents coefficient estimates from separate regressions estimated by level of individualism. The bottom panel presents coefficient estimates from separate regressions estimated by strength of creditor rights. A full set of controls, year and industry fixed effects are included but not reported, and ${ }^{* * *},{ }^{* *}$, and ${ }^{*}$ denotes statistical significance at the 1,5 , and $10 \%$ levels, respectively. The bottom rows of each panel reports estimates of the economic significance of creditor rights and individualism. The figures reported for creditor rights relate to the predicted payout amount for creditor rights ranging from zero to four. For individualism, the figures reported relate to the predicted payout amount ranging from an average of the bottom two to an average of the top two scores for individualism. The predicted payouts are calculated by evaluating all independent variable at their sample medians, for the year 2005 and for industrial firms. Predicted dividends-to-asset (\%) and dividends-to-sales (\%) are also reported.

prevails, the relationship between dividend payout and creditor rights, and dividend payer and creditor rights, is negative. These findings serve to remove the ambiguity surrounding the relationship between dividend payout and creditor rights in collectivist countries which we stated earlier in developing hypotheses 1 .

The middle rows of Table 6 explore whether our findings have economic as well as statistical significance. Our in-sample dividend payout predictions suggest that they do. For example, in individualist cultures, dividends-to-cash flow is restricted to just $5.4 \%$ for the median firm where creditor rights is zero, yet is $11.3 \%$ in collectivist cultures where creditor rights is just as low. Where creditor rights are strong, dividends paid are much larger in individualist cultures.

The bottom rows of Table 6 test hypothesis 2, which predicts that dividend payouts are positively related to individualism when creditor rights are strong. Using the dividend amount (dividends relative to cash flow, earnings, assets, and sales, as indicated), we always find a positive estimated coefficient for individualism under strong creditor rights. This finding suggests that in individualist societies where ties between individuals are loose and agency conflict more severe, dividend payouts are large. Where creditor rights are strong, these large dividend payouts are maintained. In contrast, where creditor rights are weak, creditors place large restrictions on dividend payouts. When creditor protection is weak, the estimated coefficient on individualism is negative and statistically significant.

*Once again we can attach both economic and statistical significance to our findings. A worst-to-best change in individualism results in a change in dividends-to-cash flow from 12.3 to $13.2 \%$ under strong creditor rights, yet a decrease from 20.4 to $5.1 \%$ under weak creditor rights. Where creditor rights are weak, creditors place large restrictions on dividend payout in individualist, but not in collectivist, traditions. Tests of hypothesis 2 using payer are reported in the furthest right column of Table 6. Using payer the estimated coefficient for individualism is negative $\left(-0.002^{* * *}\right)$ under strong creditor rights, and not positive as expected. However, under weak creditor rights, the estimated coefficient for individualism is negative and larger $\left(-0.004^{* * *}\right)$, which together with the estimated coefficient under strong creditor rights, lends support the main premise of hypothesis 2 . That is, under weak creditor rights, the dividend amount is smaller and the likelihood of paying a dividend is much lower in individualist traditions.

In Tables 7 and 8 we assess the robustness of our findings. In each table we perform the following tests. First, a potential concern with our findings is that they may be driven by an omitted country- or firm-level variable(s) correlated with creditor rights, individualism and dividend payout. To address this concern we include a number of additional country-level variables and a single firm-level variable identified in other studies to influence corporate dividend payouts. These are dividend tax 
Table 7

Hypothesis 1: robustness tests.

\begin{tabular}{|c|c|c|c|c|}
\hline \multicolumn{5}{|l|}{ Hypothesis 1} \\
\hline \multicolumn{5}{|c|}{ "Dividend payout-creditor rights" regressions in individualist (high individualism) and collectivist (low individualism) traditions } \\
\hline & Dividends-to-cas & & Payer & \\
\hline \multicolumn{5}{|c|}{ Panel A. Coefficient estimates for creditor rights including different country- and firm-level control variables } \\
\hline Control variables added & Individualism & Collectivism & Individualism & Collectivism \\
\hline Dividend tax advantage (DTA) & $0.047^{* * *}(16.06)$ & $-0.011^{* * *}(5.88)$ & $0.017^{* * *}(11.67)$ & $-0.104^{* * *}(13.97)$ \\
\hline Labour rights & $0.047^{* * *}(12.55)$ & $0.005^{* *}(2.21)$ & $0.011^{* * *}(9.55)$ & $-0.109^{* * *}(14.39)$ \\
\hline Stock market development & $0.046^{* * *}(16.71)$ & $-0.001(0.37)$ & $0.015^{* * *}(11.68)$ & $-0.102^{* * *}(14.44)$ \\
\hline All of the above included & $0.026^{* * *}(7.03)$ & $0.000(1.20)$ & $0.010^{* * *}(6.10)$ & $-0.024^{* *}(1.96)$ \\
\hline Cash* $^{*}$ & $0.053^{* * *}(17.70)$ & $0.010^{* * *}(5.33)$ & $0.021^{* * *}(11.55)$ & $-0.106^{* * *}(15.96)$ \\
\hline \multicolumn{5}{|c|}{ Panel B. Coefficient estimates for creditor rights using dividends-to-assets } \\
\hline Creditor rights & $0.010^{* * *}(14.13)$ & $0.002^{* * *}(11.39)$ & $\mathrm{n} / \mathrm{a}$ & $\mathrm{n} / \mathrm{a}$ \\
\hline \multicolumn{5}{|c|}{ Panel C. Coefficient estimates for creditor rights using larger sample } \\
\hline Creditor rights & $0.023^{* * *}(17.38)$ & $0.011^{* * *}(6.48)$ & $0.061^{* * *}(15.01)$ & $-0.043^{* * *}(5.39)$ \\
\hline \multicolumn{5}{|c|}{ Panel D. Coefficient estimates for creditor rights using regression weights } \\
\hline Creditor rights & $0.041^{* * *}(10.62)$ & $0.010^{* * *}(2.77)$ & $0.086^{* * *}(9.50)$ & $-0.018^{*}(1.70)$ \\
\hline \multicolumn{5}{|c|}{ Panel E. Coefficient estimates for creditor rights excluding firms from Japan, UK, and the US } \\
\hline Creditor rights & $0.035^{* * *}(10.67)$ & $0.002(0.55)$ & $0.060^{* * *}(8.23)$ & $-0.077^{* * *}(5.43)$ \\
\hline \multicolumn{5}{|c|}{ Panel F. Coefficient estimates for creditor rights using Tobit estimation } \\
\hline Creditor rights & $0.029^{* * *}(51.50)$ & $-0.002^{* * *}(3.77)$ & $\mathrm{n} / \mathrm{a}$ & $\mathrm{n} / \mathrm{a}$ \\
\hline
\end{tabular}

*When we include cash as a control variable, the sample sizes in individualist and collectivist regimes are 45,283 and 44,188, respectively.

This table reports coefficient estimates for creditor rights in a series of ordinary least squares, logit and tobit regressions. Separate regressions are estimated by cultural tradition (individualism and collectivism). The dependent variable is dividends-to-cash flow, dividends-to-assets, and payer, as indicated. Panel A includes a number of additional country- and firm-level determinants of dividend payout not included previously. Panel B uses dividends-to-assets. The sample period is 1996-2007. Panel C employs a larger sample of firms over a longer time period. The larger sample includes firms from Brazil, Chile, Greece, Indonesia, Israel, Pakistan, Peru, Philippines, Portugal, South Africa, and Taiwan and the sample period extends from 1981 to 2007 . In this larger sample, the country median individualism is 51. Panels D and E address concerns that our findings are driven either by unequal number of observations across countries. In Panel D we estimate weighted least squares regressions where the weight of each observation is the inverse of the number of observations in each country, so that each country receives an equal weighting. In Panel E, firms from Japan, the UK and the US are excluded. Panel F presents coefficient estimates from tobit regressions. A full-set of firm and country controls, industry and time fixed effects are included, but not reported. All variables are defined in the main text, and ${ }^{* * *}, * *$, and ${ }^{*}$ denotes significance at the 1,5 , and $10 \%$ level, respectively.

advantage, labour rights, stock market development, and corporate cash holdings. Dividend tax advantage (DTA) measures the after-tax value of one dollar paid out in dividends divided by the after-tax value of one dollar paid out in capital gains. DTA is sourced from Bartram et al. (2012) and Fidrmuc and Jacob (2010). The relationship between dividend payout and DTA has consistently been shown in previous studies to be positive. Yu (2010) finds a negative robust relationship between labor rights and dividend payouts. We source labour rights data from Botero et al. (2004). Twu (2012) shows that stock market development can explain part of the decline in the number of firms that pay dividends in recent times. We include a measure of stock market development (stock market capitalization to GDP), which we source from an updated version of Beck et al. (2001). Finally, we include corporate cash balances as an additional firm-level control variable in all regressions. Presumably, mature firms with large cash balances, pay large dividends. Cash is calculated as cash to book assets and is sourced from Worldscope. ${ }^{11}$ The first five rows in Panel A of Tables 7 and 8 report the coefficient estimates for creditor rights (Table 7) and individualism (Table 8) after adding DTA, labor rights, stock market development, all three country-level variables together, and cash to our baseline regressions reported in Panels A and B of Table 6.

In panel B we report the estimated coefficients for creditor rights (Table 7) and individualism (Table 8) when we use dividends-to-assets in place of dividends-to-cash flow and dividends-to-earnings. In panel $\mathrm{C}$ we address concerns that our findings may not be universal but specific to the sample of firms we use and the period we cover. To address these concerns, we extend our sample to span the years from 1981 to 2007, and include firms from countries with mandatory dividends and firms we previously eliminated because a disclosure score was not available for their country. The extended sample now includes firms from Brazil, Chile, Greece, Indonesia, Israel, Pakistan, Peru, Philippines, Portugal, South Africa, and Taiwan, which increases the number of countries from 28 to 39. This sample covers the period from 1981 to 2007 and results in a total of 186,833 firm-year observations. ${ }^{12}$ Appendix D outlines the sample size, dividend payout, creditor rights and individualism for each of these countries. Dividends-to-cash flow ranges from 0 to 0.19 , and creditor rights and individualism from 0 to 3 , and 11-65, respectively. Where the larger and extended sample of firms is employed, country-level shareholder rights, measured using the revised anti-director rights index from Djankov et al. (2008) is included in place of disclosure. ${ }^{13}$ Next

\footnotetext{
11 The inclusion of cash reduces our sample size to 89,471 firm-year observations.

12 In the extended and larger sample, median creditor rights remains at 2 . Median individualism is 51.

13 The values of DTA, labor rights, stock market development, revised anti-director rights, and financial architecture are presented for each country in Appendix C. In an additional set of (unreported) robustness tests, we find that our findings are unaffected when we simultaneously include disclosure and revised anti-director rights in the same regressions.
} 
Table 8

Hypothesis 2: robustness tests.

\begin{tabular}{|c|c|c|c|c|}
\hline \multicolumn{5}{|l|}{ Hypothesis 2} \\
\hline \multicolumn{5}{|c|}{ “Dividend payout-individualism” regressions in strong (high creditor rights) and weak creditor rights (low creditor rights) countries } \\
\hline & Dividends-to-cas & & Payer & \\
\hline \multicolumn{5}{|c|}{ Panel A. Coefficient estimates for individualism including different country- and firm-level control variables } \\
\hline Control variables added & $\begin{array}{l}\text { Strong Creditor } \\
\text { rights regime }\end{array}$ & $\begin{array}{l}\text { Weak Creditor } \\
\text { rights regime }\end{array}$ & $\begin{array}{l}\text { Strong Creditor } \\
\text { rights regime }\end{array}$ & $\begin{array}{l}\text { Weak Creditor } \\
\text { rights regime }\end{array}$ \\
\hline Dividend tax advantage (DTA) & $0.001^{* * *}(3.01)$ & $-0.002^{* * *}(20.77)$ & $-0.002^{* * *}(3.63)$ & $-0.005^{* * *}(21.47)$ \\
\hline Labour rights & $0.001 *(1.94)$ & $-0.002^{* * *}(16.47)$ & $-0.002^{* * *}(3.83)$ & $-0.004^{* * *}(16.65)$ \\
\hline Stock market development & $0.001(1.75)^{*}$ & $-0.002^{* * *}(20.36)$ & $-0.002^{* * *}(4.20)$ & $-0.004^{* * *}(19.25)$ \\
\hline All of the above included & $0.004 *(1.76)$ & $-0.002^{* * *}(15.69)$ & $-0.002^{* * *}(3.85)$ & $-0.004^{* * *}(16.86)$ \\
\hline Cash* & $0.001 *(1.73)$ & $-0.002^{* * *}(19.97)$ & $-0.002^{* * *}(3.97)$ & $-0.006^{* * *}(18.34)$ \\
\hline \multicolumn{5}{|c|}{ Panel B. Coefficient estimates for individualism using dividends-to-assets } \\
\hline Individualism & $0.001 *(1.82)$ & $-0.0003^{* * *}(14.18)$ & $\mathrm{n} / \mathrm{a}$ & $\mathrm{n} / \mathrm{a}$ \\
\hline \multicolumn{5}{|c|}{ Panel C. Coefficient estimates for individualism using larger sample } \\
\hline Individualism & $0.001^{* * *}(7.26)$ & $-0.001^{* * *}(24.95)$ & $-0.001^{* * *}(4.91)$ & $-0.010^{* * *}(40.84)$ \\
\hline \multicolumn{5}{|c|}{ Panel D. Coefficient estimates for individualism using regression weights } \\
\hline Individualism & $0.001^{* * *}(5.43)$ & $-0.002^{* * *}(10.79)$ & $-0.001^{* * *}(3.44)$ & $-0.002^{* * *}(3.73)$ \\
\hline \multicolumn{5}{|c|}{ Panel E. Coefficient estimates for individualism excluding firms from Japan, UK, and the US } \\
\hline Individualism & $0.001^{*}(1.68)$ & $-0.002^{* * *}(13.47)$ & $-0.002^{* * *}(3.96)$ & $-0.004^{* * *}(7.34)$ \\
\hline \multicolumn{5}{|c|}{ Panel F. Coefficient estimates for individualism excluding countries with creditor rights equal to two } \\
\hline Individualism & $0.001(0.61)$ & $-0.002^{* * *}(5.95)$ & $-0.002^{* * *}(4.46)$ & $-0.004^{* * *}(9.21)$ \\
\hline \multicolumn{5}{|c|}{ Panel G. Coefficient estimates for individualism using Tobit estimation } \\
\hline Individualism & $0.004^{* * *}(6.96)$ & $-0.002^{* * *}(97.04)$ & $\mathrm{n} / \mathrm{a}$ & $\mathrm{n} / \mathrm{a}$ \\
\hline
\end{tabular}

*When we include cash as a control variable, the sample sizes in strong and weak creditor rights regimes are 35,902 and 53,569, respectively.

This table reports coefficient estimates for individualism in a series of regressions. Separate regressions are estimated by strength of creditor rights. The dependent variable is dividends-to-cash flow, dividends-to-assets, and payer, as indicated. Panel A includes a number of additional country- and firm-level determinants of dividend payout not included previously. Panel B uses dividends-to-assets. The sample period is 1996-2007. Panel C employs a larger sample of firms over a longer time period. The larger sample includes firms from Brazil, Chile, Greece, Indonesia, Israel, Pakistan, Peru, Philippines, Portugal, South Africa, and Taiwan and the sample period extends from 1981 to 2007 . Panels D and E address concerns that our findings are driven either by unequal number of observations across countries. In Panel D we estimate weighted least squares regressions where the weight of each observation is the inverse of the number of observations in each country, so that each country receives an equal weighting. In Panel E, firms from Japan, the UK and the US are excluded. Panel F excludes countries with a creditor rights score of 2. Panel G presents coefficient estimates from tobit regressions. A full-set of firm and country controls, industry and time fixed effects are included, but not reported. All variables are defined in the main text, and ***, **, and * denotes significance at the 1,5 , and $10 \%$ level, respectively.

we address concerns that our findings are unduly influenced by sample-bias created by the large number of firms in the U.S., the U.K., and Japan. We address this concern in two-ways. First, we estimate a series of weighted least squares regressions where the weight of each observation is the inverse of the number of observations in each country so that each country receives an equal-weighting. We also test hypotheses 1 and 2 without firms from the U.S., the U.K., and Japan. In Table 8 we address a concern that our tests of hypothesis 2 are influenced by how we differentiate between strong and weak creditor rights. While it is reasonable to assume that creditor protection is weak given scores of 0 and 1 , and strong given scores of 3 and 4, a creditor rights score of 2 is at the margin. In these tests we exclude countries with a creditor rights score of 2. Finally, in the last panel of Tables 7 and 8, we estimate Tobit models to account for the censored nature of our dividend payout ratios (censored at zero).

In summary we find that our findings are qualitatively unaffected given the battery of tests we perform in Tables 7 and 8 . The dividend-creditor rights relationship is positive in individualist traditions, while much smaller and often negative in collectivist traditions. The dividend-individualism relation is positive under strong creditor rights and negative under weak creditor rights.

\section{Concluding remarks}

In this paper we exploit cross-country variation in creditor rights and culture, proxied using individualism, and explore how they interact with each other to influence corporate dividend policy. Our findings support the contention of, among others, Aggarwal and Goodell (2014), who argue that ignoring the impact of national culture in finance research is not an optimal strategy and that there is plenty of scope for strengthening finance research by incorporating the impact of cultural dimensions. Previous studies which explore how the agency costs of debt together with the agency costs of equity influence corporate dividend policy have failed to acknowledge the role national culture might play. Our findings suggest that creditors influence over corporate payout policy is determined not only by the strength of creditor rights but also by culture. Where creditor rights are strong, creditors accept the status quo, that is, large dividends in individualist traditions, and small dividend payouts in collectivist cultures. The interaction of creditor rights and culture arises when creditor rights are weak. In individualist traditions, where agency costs of debt are high according to the law and culture, creditors place 
large restrictions on dividend payouts. In contrast where agency costs of debt are high as implied by weak creditor rights, yet low according to culture, creditors place few if any restrictions on dividend payouts. In this instance culture overrides legal rules to determine creditors influence over corporate dividend policy.

Our findings have important implications for the dividend creditor rights and dividend-individualism relations. In a sample of 17,544 firms from 28 countries, we show that the dividend creditor rights relationship is positive in individualist traditions yet negative in many instances in collectivist cultures. The dividend-individualism relationship is positive under strong creditor rights yet negative under weak creditor rights. Where creditor rights are weak, creditor rights and culture come together to influence corporate dividend policy.

\section{Acknowledgements}

This paper has benefitted greatly from comments received from an anonymous referee, and seminar participants at University College Dublin and the University of Limerick. We thank Sohnke Bartram for sharing his dividend tax advantage data with us. Any remaining errors are our own.

\section{Appendix A. Median dividend payout by individualism and creditor rights regimes}

This table reports the median dividend payout in countries differentiated by culture and creditor rights. Median dividend payout is reported for each country and the average and median of these median payouts is presented underneath. Separate figures are also reported for weak creditor rights regimes where countries with a creditor rights score of two are excluded, and without firms from the United Kingdom, the United States and Japan. The median figures for the full sample are reported in Table 4.

\begin{tabular}{|c|c|c|c|c|c|c|c|}
\hline \multicolumn{8}{|l|}{ Hypothesis 1} \\
\hline \multicolumn{8}{|c|}{ The relationship between dividend payout and creditor rights under individualist and collectivist cultural traditions } \\
\hline \multicolumn{4}{|c|}{ Individualism and Strong Creditor rights } & \multicolumn{4}{|c|}{ Individualism and Weak Creditor rights } \\
\hline & $\mathrm{D} / \mathrm{CF}$ & $\mathrm{D} / \mathrm{E}$ & Pay & & $\mathrm{D} / \mathrm{CF}$ & $\mathrm{D} / \mathrm{E}$ & Pay \\
\hline Australia & 0.00 & 0.00 & 0.55 & Belgium & 0.09 & 0.24 & 0.79 \\
\hline Denmark & 0.09 & 0.20 & 0.85 & Canada & 0.00 & 0.00 & 0.00 \\
\hline Netherlands & 0.18 & 0.33 & 0.82 & France & 0.08 & 0.19 & 0.72 \\
\hline New Zealand & 0.32 & 0.54 & 0.85 & Ireland & 0.12 & 0.18 & 0.69 \\
\hline \multirow[t]{4}{*}{ United Kingdom } & 0.13 & 0.22 & 0.65 & Italy & 0.09 & 0.25 & 0.80 \\
\hline & & & & Norway & 0.00 & 0.00 & 0.62 \\
\hline & & & & Sweden & 0.10 & 0.19 & 0.61 \\
\hline & & & & United States & 0.00 & 0.00 & 0.00 \\
\hline Median & 0.13 & 0.22 & 0.82 & Median & 0.09 & 0.19 & 0.66 \\
\hline Average & 0.14 & 0.26 & 0.74 & Average & 0.06 & 0.13 & 0.53 \\
\hline \multirow[t]{4}{*}{ Median (excl. UK) } & 0.14 & 0.27 & 0.84 & Median (excl. US) & 0.09 & 0.19 & 0.69 \\
\hline & & & & \multicolumn{4}{|c|}{ Excluding countries with creditor rights score of 2} \\
\hline & & & & Median & 0.08 & 0.18 & 0.61 \\
\hline & & & & Average & 0.06 & 0.11 & 0.40 \\
\hline
\end{tabular}

\begin{tabular}{|c|c|c|c|c|c|c|c|}
\hline \multicolumn{8}{|c|}{ Hypothesis 2} \\
\hline \multicolumn{8}{|c|}{ The relationship between dividend payout and individualism under strong and weak creditor rights } \\
\hline \multicolumn{4}{|c|}{ Collectivism and Strong Creditor rights } & \multicolumn{4}{|c|}{ Collectivism and Weak Creditor rights } \\
\hline & $\mathrm{D} / \mathrm{CF}$ & $\mathrm{D} / \mathrm{E}$ & Pay & & $\mathrm{D} / \mathrm{CF}$ & $\mathrm{D} / \mathrm{E}$ & Pay \\
\hline Austria & 0.12 & 0.29 & 0.81 & Argentina & 0.00 & 0.00 & 0.70 \\
\hline Germany & 0.00 & 0.00 & 0.59 & Finland & 0.22 & 0.41 & 0.87 \\
\hline Hong Kong & 0.00 & 0.00 & 0.64 & India & 0.14 & 0.21 & 0.94 \\
\hline Korea & 0.04 & 0.11 & 0.79 & Japan & 0.09 & 0.22 & 0.92 \\
\hline Malaysia & 0.07 & 0.13 & 0.76 & Mexico & 0.00 & 0.00 & 0.63 \\
\hline \multirow[t]{4}{*}{ Singapore } & 0.10 & 0.18 & 0.82 & Spain & 0.14 & 0.26 & 0.83 \\
\hline & & & & Switzerland & 0.12 & 0.25 & 0.86 \\
\hline & & & & Thailand & 0.12 & 0.25 & 0.83 \\
\hline & & & & Turkey & 0.00 & 0.00 & 0.52 \\
\hline Median & 0.05 & 0.12 & 0.78 & Median & 0.12 & 0.22 & 0.83 \\
\hline \multirow[t]{5}{*}{ Average } & 0.06 & 0.12 & 0.74 & Average & 0.09 & 0.18 & 0.79 \\
\hline & & & & Median (excl. Japan) & 0.12 & 0.23 & 0.83 \\
\hline & & & & \multicolumn{4}{|c|}{ Excluding countries with creditor rights score of 2} \\
\hline & & & & Median & 0.06 & 0.13 & 0.78 \\
\hline & & & & Average & 0.09 & 0.17 & 0.77 \\
\hline
\end{tabular}


Appendix B. Variable descriptions

\begin{tabular}{|c|c|c|c|}
\hline Variable & Description & Source & Coverage \\
\hline Dividends-to-cash flow & Dividends per share/cash flow per share & Worldscope & $1996-2007$ \\
\hline Dividends-to-earnings & Dividends per share/earnings per share & Worldscope & $1996-2007$ \\
\hline Dividends-to-assets & Total (common) dividends to total assets & Worldscope & $1996-2007$ \\
\hline Dividends-to-sales & Total (common) dividends to total sales & Worldscope & 1996-2007 \\
\hline Payer & $\begin{array}{l}1 \text { if the firm pays a dividend in year } t \text {, zero } \\
\text { otherwise }\end{array}$ & Worldscope & 1996-2007 \\
\hline Size & $\begin{array}{l}\text { Log of book assets in US\$ (Log of book sales in } \\
\text { US\$ used in div-to-assets regressions) }\end{array}$ & Worldscope & 1996-2007 \\
\hline Growth & Logarithmic one-year sales growth & Worldscope & 1996-2007 \\
\hline Profitability & $\begin{array}{l}\text { Earnings before interest and taxation to book } \\
\text { assets }\end{array}$ & Worldscope & 1996-2007 \\
\hline Leverage & Total debt to total assets & Worldscope & 1996-2007 \\
\hline Tobin's $q$ & $\begin{array}{l}\text { Tobin's } q \text { is defined as the book value of debt } \\
\text { less plus market capitalization divided by the } \\
\text { book value of assets }\end{array}$ & Worldscope & 1996-2007 \\
\hline Cash & Cash to book assets & Worldscope & $1996-2007$ \\
\hline Creditor rights & $\begin{array}{l}\text { An index aggregating creditor rights, following } \\
\text { La Porta et al. ( } 2000 \text { ). The index ranges from } 0 \\
\text { (weak) to } 4 \text { (strong creditor rights) and is } \\
\text { constructed as at January for every year from } \\
1978 \text { to } 2003 \text {. We use creditor rights data for } \\
\text { the year } 2002\end{array}$ & Djankov et al. (2007) & 2002 \\
\hline Individualism & $\begin{array}{l}\text { Captures the extent of individualism and } \\
\text { collectivism in a society. Individualism and } \\
\text { collectivism are defined in the main text }\end{array}$ & Hofstede (2001) & Various years \\
\hline Disclosure & $\begin{array}{l}\text { Country-level accounting disclosure score } \\
\text { assigned by Center for International Financial } \\
\text { Analysis and Research (CIFAR) }\end{array}$ & $\begin{array}{l}\text { CIFAR (1995) and Hope et al. } \\
\text { (2007) }\end{array}$ & 1993 \\
\hline Labour rights & $\begin{array}{l}\text { Employment laws index from Botero et al. } \\
\text { (2004). The employment laws index combines } \\
\text { four sub-indexes, namely ( } 1 \text { ) alternative } \\
\text { employment contracts, (2) cost of increasing } \\
\text { hours worked, ( } 3 \text { ) cost of firing workers, and } \\
\text { (4) dismissal procedures. }\end{array}$ & Botero et al. (2004) & 1997 \\
\hline Stock market development & $\begin{array}{l}\text { Stock market capitalization to GDP in each } \\
\text { year from } 1996 \text { to } 2007\end{array}$ & Beck et al. (2001) (updated) & 1996-2007 \\
\hline Dividend tax advantage & $\begin{array}{l}\text { The after-tax value of one dollar paid out in } \\
\text { dividends divided by the after-tax value of one } \\
\text { dollar paid out in capital gains. Dividend tax } \\
\text { advantage is for } 2001\end{array}$ & $\begin{array}{l}\text { Bartram et al. (2012) and } \\
\text { Fidrmuc and Jacob (2010) }\end{array}$ & 2001 \\
\hline Shareholder rights & $\begin{array}{l}\text { Revised version of the original anti-director } \\
\text { rights index of La Porta et al. (2000) }\end{array}$ & Djankov et al. (2008) & 1997 \\
\hline Dividend premium & $\begin{array}{l}\text { The ratio of the average market-to-book of } \\
\text { dividend paying firms to the average } \\
\text { market-to-book of non-paying firms. Dividend } \\
\text { premium is calculated annually for each } \\
\text { country }\end{array}$ & Worldscope & 1996-2007 \\
\hline
\end{tabular}

\section{Appendix C. Country-level variables}

This table reports country-level variables for our sample of countries. Dividend tax advantage variable measures the after-tax value of one dollar paid out in dividends divided by the after-tax value of one dollar paid out in capital gains, and is sourced from Bartram et al. (2012) and Fidrmuc and Jacob (2010). Disclosure is a country's disclosure score assigned by the Center for International Financial Analysis and Research (CIFAR, 1995). Labour rights are sourced from Botero et al. (2004). Stock market development is stock market capitalization to GDP and is sourced from an updated version of Beck et al. (2001). Dividend premium is computed annually for each country and is computed as the ratio of the average market-to-book of dividend paying firms to the average market-to-book of non-paying firms. Shareholder rights are the revised anti-director rights index of Djankov et al. (2008). 


\begin{tabular}{|c|c|c|c|c|c|c|}
\hline & $\begin{array}{l}\text { Dividend tax } \\
\text { advantage (DTA) }\end{array}$ & Disclosure & Labour rights & Stock market dev & Dividend premium & $\begin{array}{l}\text { Shareholder rights } \\
\text { (Revised ADR Index) }\end{array}$ \\
\hline Argentina & 1.0000 & 68 & 0.3442 & 38.58 & 1.24 & 2 \\
\hline Australia & 0.8372 & 80 & 0.3515 & 110.06 & 0.95 & 4 \\
\hline Austria & 0.7500 & 62 & 0.5007 & 23.30 & 0.79 & 2.5 \\
\hline Belgium & 0.8500 & 68 & 0.5133 & 68.27 & 0.95 & 3.0 \\
\hline Canada & 0.7905 & 75 & 0.2615 & 107.40 & 0.81 & 4 \\
\hline Denmark & 0.6387 & 75 & 0.5727 & 57.90 & 0.90 & 4 \\
\hline Finland & 1.0782 & 83 & 0.7366 & 130.08 & 1.06 & 3.5 \\
\hline France & 0.6569 & 78 & 0.7443 & 79.47 & 0.99 & 3.5 \\
\hline Germany & 0.7276 & 67 & 0.7015 & 47.11 & 1.07 & 3.5 \\
\hline Hong Kong & 1.0000 & 73 & 0.1696 & 339.12 & 0.83 & 5 \\
\hline India & 0.7435 & 61 & 0.4434 & 47.40 & 1.49 & 5 \\
\hline Ireland & 0.6105 & 81 & 0.3427 & 59.74 & 0.75 & 5 \\
\hline Italy & 0.8726 & 66 & 0.6499 & 44.62 & 1.07 & 2 \\
\hline Japan & 0.5797 & 71 & 0.1639 & 78.06 & 0.92 & 4.5 \\
\hline Korea & 0.6895 & 68 & 0.4457 & 55.46 & 0.82 & 4.5 \\
\hline Malaysia & 1.0000 & 79 & 0.1885 & 141.56 & 0.96 & 5 \\
\hline Mexico & 1.0000 & 71 & 0.5943 & 23.41 & 1.24 & 3 \\
\hline Netherlands & 0.7000 & 74 & 0.7256 & 113.96 & 0.82 & 2.5 \\
\hline New Zealand & 1.0088 & 80 & 0.1607 & 39.54 & 1.07 & 4 \\
\hline Norway & 1.0753 & 75 & 0.6853 & 44.73 & 0.89 & 3.5 \\
\hline Singapore & 0.9713 & 79 & 0.3116 & 185.63 & 0.94 & 5 \\
\hline Spain & 0.8509 & 72 & 0.7447 & 71.37 & 0.94 & 5 \\
\hline Sweden & 0.7568 & 83 & 0.7405 & 104.83 & 0.87 & 3.5 \\
\hline Switzerland & 0.5850 & 80 & 0.4520 & 229.64 & 1.04 & 3 \\
\hline Thailand & 1.0286 & 66 & 0.4097 & 51.56 & 0.99 & 4 \\
\hline Turkey & 0.6168 & 58 & 0.4026 & 22.40 & 1.13 & 3 \\
\hline Utd Kingdom & 0.8571 & 85 & 0.2824 & 141.99 & 0.82 & 5 \\
\hline United States & 0.7033 & 76 & 0.2176 & 135.07 & 0.85 & 3 \\
\hline
\end{tabular}

\section{Appendix D. Countries included in extended sample}

Panel A reports summary statistics for firms from countries not included in the original sample. \# Obs is the number of firm-year observations, and \# Firms, the number of firms in each country. Median dividend payout is reported for each country. Dividend payout is dividends-to-cash flow (Div/CF), dividends-to-earnings (Div/E), as indicated. Payer is the proportion of firms in each country which pay a dividend. Payer is first calculated on a yearly basis from 1981 to 2007, and I report the median payer for each country over this time interval. Creditor rights are from Djankov et al. (2007) and correspond to values in 2002. Individualism is from Hofstede (2001). Panel B outlines the number of firm-years (\#Obs) and firms for each country in the original sample of firms examined over the extended sample period. Dividend payout data is from Worldscope. 


\begin{tabular}{|c|c|c|c|c|c|c|c|}
\hline \multicolumn{8}{|l|}{ Panel A } \\
\hline & \multicolumn{2}{|l|}{ Sample } & \multicolumn{3}{|c|}{ Dividend payout measures } & \multirow[t]{2}{*}{ Creditor rights } & \multirow[t]{2}{*}{ Individualism } \\
\hline & \# Obs & \# Firms & $\mathrm{Div} / \mathrm{CF}$ & Div/E & Payer & & \\
\hline Brazil & 1572 & 209 & 0.03 & 0.19 & 0.56 & 1 & 38 \\
\hline Chile & 951 & 119 & 0.19 & 0.34 & 0.75 & 2 & 23 \\
\hline Greece & 1771 & 238 & 0.16 & 0.34 & 0.68 & 1 & 35 \\
\hline Indonesia & 2059 & 250 & 0.00 & 0.00 & 0.33 & 2 & 14 \\
\hline Israel & 511 & 92 & 0.00 & 0.00 & 0.30 & 3 & 54 \\
\hline Pakistan & 937 & 93 & 0.12 & 0.22 & 0.60 & 1 & 14 \\
\hline Peru & 379 & 55 & 0.00 & 0.00 & 0.43 & 0 & 11 \\
\hline Philippines & 921 & 118 & 0.00 & 0.00 & 0.33 & 1 & 32 \\
\hline Portugal & 548 & 58 & 0.05 & 0.19 & 0.54 & 1 & 27 \\
\hline South Africa & 2341 & 267 & 0.15 & 0.25 & 0.59 & 3 & 65 \\
\hline \multirow[t]{2}{*}{ Taiwan } & 6479 & 1121 & 0.10 & 0.19 & 0.62 & 2 & 17 \\
\hline & 18,469 & 2620 & & & & & \\
\hline
\end{tabular}

Panel B

Number of firm-years and firms for original country sample over extend sample period

\begin{tabular}{|c|c|c|c|c|c|}
\hline & \# Obs & \# Firms & & \# Obs & \# Firms \\
\hline Argentina & 413 & 51 & Korea & 5749 & 789 \\
\hline Australia & 5038 & 788 & Malaysia & 6067 & 806 \\
\hline Austria & 651 & 60 & Mexico & 892 & 100 \\
\hline Belgium & 1008 & 90 & Netherlands & 1923 & 146 \\
\hline Canada & 6828 & 860 & New Zealand & 593 & 73 \\
\hline Denmark & 1396 & 120 & Norway & 1164 & 132 \\
\hline Finland & 1214 & 114 & Singapore & 3584 & 516 \\
\hline France & 6671 & 647 & Spain & 1192 & 104 \\
\hline Germany & 6342 & 662 & Sweden & 2382 & 275 \\
\hline Hong Kong & 5448 & 739 & Switzerland & 2218 & 183 \\
\hline India & 3804 & 509 & Thailand & 2873 & 347 \\
\hline Ireland & 643 & 49 & Turkey & 1078 & 171 \\
\hline Italy & 1815 & 181 & United Kingdom & 14,113 & 1388 \\
\hline Japan & 34,059 & 3374 & United States & 49,206 & 4832 \\
\hline
\end{tabular}

\section{References}

Aggarwal, R., Goodell, J., 2014. Culture, institutions, and financing choices: how and why are they related? Res. Int. Bus. Finance 31, $101-111$.

Bae, S., Chang, K., Kang, E., 2012. Culture, corporate governance, and dividend policy: international evidence. J. Financial Res. 35, $289-316$.

Baker, M., Wurgler, J., 2004. A catering theory of dividends. J. Finance 59, 1125-1165.

Bartram, S., Brown, P., How, J., Verhoeven, P., 2012. Agency Conflicts and Corporate Payout Policies: A Global Study. Lancaster University, working Paper. Beck, T., Demirguc-Kunt, A., Levine, R., 2001. A new database on financial development and structure. World Bank Econ. Rev. 14, 597-605.

Botero, J., Djankov, S., La Porta, R., Lopez-de-Silanes, F., Shleifer, A., 2004. The regulation of labor. Q. J. Econ. 119, $1339-1382$.

Brockman, P., Unlu, E., 2009. Dividend policy, creditor rights, and the agency costs of debt. J. Financial Econ. 92, $276-299$.

Brockman, P., Unlu, E., 2011. Earned/contributed capital, dividend policy, and disclosure quality: an international study. J. Bank. Finance 35, $1610-1625$.

Bulan, L., Subramanian, N., 2009. The firm life-cycle theory of dividends. In: Baker, H. Kent (Ed.), Dividends and Dividend Policy. Wiley.

Byrne, J., O'Connor, T., 2012. Creditor rights and the outcome model of dividends. Q. R. Econ. Finance 52, $227-242$.

Chae, J., Kim, S., Lee, E., 2009. How corporate governance affects payout policy under agency problems and external financing constraints. J. Bank. Finance $33,2093-2101$.

Chui, A., Lloyd, A., Kwok, C., 2002. The determination of capital structure: is national culture a missing piece of the puzzle? J. Int. Bus. Stud. 33, 99-127. Claessens, S., Yurtoglu, B., 2013. Corporate governance in emerging markets: a survey. Emerg. Mark. Rev. 15, 1-33.

DeAngelo, H., DeAngelo, L., Stulz, R., 2006. Dividend policy and the earned/contributed capital mix: a test of the life-cycle theory. J. Financial Econ. 81, $227-254$

Denis, D., Osobov, I., 2008. Why do firms pay dividends? International evidence on the determinants of dividend policy. J. Financial Econ. 89, 62-82.

Dey, A., 2008. Corporate governance and agency conflicts. J. Account. Res. 46, 1143-1181.

Djankov, S., McLeish, C., Shleifer, A., 2007. Private credit in 129 countries. J. Financial Econ. 84, 299-329.

Djankov, S., LaPorta, R., Lopez-de-Silanes, F., Shleifer, A., 2008. The law and economics of self-dealing. J. Financial Econ. 88, $430-465$.

Easterbrook, F., 1984. Two agency-cost explanations of dividends. Am. Econ. Rev. 74, 650-659.

Faccio, M., Lang, L., Young, L., 2001. Dividends and expropriation. Am. Econ. Rev. 91, 54-78.

Fidrmuc, J., Jacob, M., 2010. Culture, agency costs, and dividends. J. Comp. Econ. 38, 321-339.

Gan, J., Lemmon, M., Wang, M., 2013. Can Firms Build Capital-Market Reputation to Substitute for Poor Investor Protection? Evidence from Dividend Policies. University of Science and Technology, Hong Kong, working paper.

Gomes, A., 2000. Going public without governance: managerial reputation effects. J. Finance 55, 615-646.

Griffin, D., Guedhami, O., Kwok, C., Li, K., Shao, L., 2014. National Culture, Corporate Governance Practices, and Firm Performance. University of British Colombia, working paper.

Hofstede, G., 1980. Culture's Consequences: International Differences in Work-related Values. Sage, Thousand Oaks, CA.

Hofstede, G., 2001. Culture's Consequences: Comparing Values, Behaviours, Institutions, and Organizations Across Nations. Sage, Thousand Oaks, California.

Hope, O.-K., Kang, T., Zang, Y., 2007. Bonding to the improved disclosure environment in the US: firms listing choices and their capital market consequences. J. Contemp. Account. Econ. 3, 1-33.

Jensen, M., 1986. Agency costs of free cash flow, corporate finance and takeovers. Am. Econ. Rev. 76, 323-339.

Jiraporn, P., Ning, Y., 2006. Dividend policy, shareholder rights, and corporate governance. J. Appl. Finance 16, 24-36.

Jiraporn, P., Kim, Y., Kim, J., 2011. Dividend policy and corporate governance quality: evidence from ISS. Financial Rev. 46, $251-279$.

John, K., Knyazeva, A., 2006. Payout Policy, Agency Conflicts, and Corporate Governance. New York University, working paper. 
Khambata, D., Liu, W., 2006. Cultural dimensions, risk aversion and corporate dividend policy. J. Asia-Pacific Bus. 6, 31-43.

La Porta, R., Lopez-de-Silanes, F., Shleifer, A., Vishny, R., 2000. Agency problems and dividend policy around the world. J. Finance 55, 1-33.

Lang, L., Litzenberger, R., 1989. Dividend announcements: cash flow signalling versus free cash flow hypothesis. J. Financial Econ. $24,181-191$.

Lievenbruck, M., Schmid, T., 2014. Why do firms (not) hedge? Novel evidence on cultural evidence. J. Corporate Finance 25, $92-106$.

Mitton, T., 2004. Corporate governance and dividend policy in emerging markets. Emerg. Mark. Rev. 5, 409-426.

Officer, M., 2006. Dividend Policy, Dividend Initiations and Governance. University of Southern California, Los Angeles, working paper.

Petersen, M., 2009. Estimating standard errors in finance panel data sets: comparing approaches. Rev. Financial Stud. 22, 435-480.

Rozeff, M., 1982. Growth, beta, and agency costs as determinants of dividend payout ratios. J. Financial Res. 5, $249-259$.

Shao, L., Kwok, C., Guedhami, O., 2010. National culture and dividend policy. J. Int. Bus. Stud. 41, 1391-1414.

Shao, L., Kwok, C., Guedhami, O., 2013. Dividend policy: balancing interests between shareholders and creditors. J. Financial Res. 36, 43-66.

Tse, C., 2004. A critique of the logic of the agency costs theory for dividends in the finance literature. J. Interdiscip. Econ. 15, 25-40.

Twu, M., 2012. Stock market development and the decline of the proportion of dividend payers' throughput the world. Financial Rev. 47, 401-421.

Yu, B., 2010. Employee Rights and Dividend Policy Around the World. Meredith College, working paper.

Zheng, X., Ghoul, S., Guedhami, O., Kwok, C., 2012. National culture and corporate debt maturity. J. Bank. Finance 36, $468-488$. 